Our Nature 2013, 11(2): 168-176

\title{
Impacts of Damming on Ichthyo-faunal Diversity of Marshyangdi River in Lamjung district, Nepal
}

\author{
Ram Bhajan Mandal* and Dilip Kumar Jha \\ Institute of Agriculture and Animal Science Rampur Campus, Tribhuvan University, Chitwan, Nepal \\ *E-mail: rbmandal2008@gmail.com
}

Received: 13.06.2013; Accepted: 13.10.2013

\begin{abstract}
A study was conducted to assess the impacts of dam on fish diversity of Marshyangdi River and its tributaries in Lamjung district. Twenty six species of fishes belonging to 5 orders, 6 families and 18 genera were recorded from the different localities. Cyprinidae was the most dominant among the families represented by $53.8 \%$ species followed by Cobitidae (23.0\%), Sisoridae $(7.7 \%)$ and Channidae $(7.7 \%)$ while Anguillidae and Synbranchidae accounted each by $3.9 \%$ only. Gut contents of fish species recorded were studied. Site specific presence of fish species indicated that damming on the main river affected the movement of migratory fishes.
\end{abstract}

Key words: Fish diversity, migratory fish, cobitidae, dam impacts, food items, Lamjung

\section{Introduction}

Nepal is a small land linked country possesses $2.27 \%$ of the water resources in the world has great potential for hydropower generation (Rai, 2008; Gubhaju, 2012). Most of the river systems in Nepal are the shelter of 217 indigenous fish species (Shrestha, 2008). The aquatic lives of the precious water resources of the nation are mostly threatened when compared with other ecosystems (Rai, 2008). Marshyangdi River is one of the hydropower potential rivers owing its gradient topography that extends from Himalayas region to terai region. The Middle Marshyangdi hydro-electric concrete dam is situated at Phalia Sangu of Lamjung district.

Lamjung district is located at the northeastern corner of the western development region of Nepal. It has subtropical climate at an average altitude of $776 \mathrm{msl}$. This region is drained by feeder streams of Majuwa, Dordi, Paundi, Naundi and many small feeder streams that finally join into Marshyangdi river. The Marshyangdi river runs $153 \mathrm{~km}$ then joins with Trisuli river at Muglin bazaar. This river originates in the Himalayas at an altitude of $6400 \mathrm{~m}$ and average slope of this river is $0.0417 \mathrm{~m}$ (Shrestha, 1999). Ichthyofaunal diversity refers to the variety of fish species; depending on context and scale, it could refer to alleles or genotypes within fish population to species of life forms within a fish community and to species or life forms across aqua regimes (Burton et al., 1992).

Site specific negative impacts of dams in different river systems in the world and Nepal have been reported (Agostinho et al., 
2008; Rai, 2008; Shrestha, 2008; Gubhaju, 2012; Sarkar et al, 2012). The damming operation should require harmonious technologies to sustain fish diversity (Jha et al., 2007). Development of appropriate technologies would be challenging for native fish conservation, general awareness, inclusion of academic courses in education (Gurung, 2012). Fish fauna are the part of National Biodiversity Conservation Strategy of Nepal (HMG/MFSC, 2002). For conservation of aquatic animals including fish, the government has promulgated Aquatic Animal Conservation Act 2005 with amendment 2001. The Act prohibits indiscriminate killing of fish and aquatic animals by unconventional methods. According to the ordinance, certain fish has been banned to be captured during the spawning season. In near future, hydropower and irrigational dams with interference to conservation of fish and fisheries would be challenging.

This paper aims to classify different fishes and their feeding behaviors. It also aims to highlight on conservation aspects of migratory fishes and damming effects and how damming has disrupted breeding habitats in Marshyangdi River.

\section{Materials and methods}

The study area along the Marshyangdi River (Fig. 1) was divided into five different localities based on abundance of fishes at confluence site of feeder streams. They were (I) North-eastern bank of Marshyangdi river at Vulvule, (II) Majuwa and Marshyangdi confluence at Besisahar, (III) Marshyangdi and Dordi confluence at Phalia sanghu, (IV) Paundi and Marshyangdi confluence at Paundi bazaar and (V) Chepe and Marshyangdi confluence at Dhameli kunwa, all lie in Lamjung district. They were visited seasonally from September 2010 to July 2011 (after the construction of middle Marshyangdi dam), to collect fish fauna of that region.

Fishing was carried out in all sampling sites with the help of locally hired fishermen. Fishes were collected with cast net and gill net. At each site, these gears were used at least ten times during each sampling event. Fishes were also collected from local market. The foregut (about 10 $\mathrm{cm}$ to esophagus) contents were removed from the specimen of all 26 species within 4 $\mathrm{hr}$ of harvest and transferred into a sterile petri-dish and viewed under a compound microscope of 10x, 40x magnifications for identification of planktons (phytoplankton and zooplankton). Planktons were analyzed according to the system developed by (Xie, 1999; Goswami, 2004; APHA, 2005; IOC, 2010). Breeding and spawning periodicity of fishes were confirmed by applying pressure on abdomen towards the genital aperture, dissection and fisherman field survey report.

Fish specimens were preserved in $10 \%$ formalin. Ecological features of the fish habitat and color of fish species were recorded throughout collection. The large specimens were incised lengthwise along the abdomen while the smaller ones were directly put into the formalin. The fish were kept upside down to avoid any damage to caudal fin in the container. For species identification, counts of lateral line scales and fin rays as well as measurement of body were made according to the system developed by Shrestha (2008). The identified specimens were preserved and kept with proper labeling in the laboratory of Lamjung Campus. The catch composition of individual fish was determined using following formula. 
Catch composition by number $(\%)=\frac{\text { Total catch of an individual species }}{\text { Total catch of all species }}$

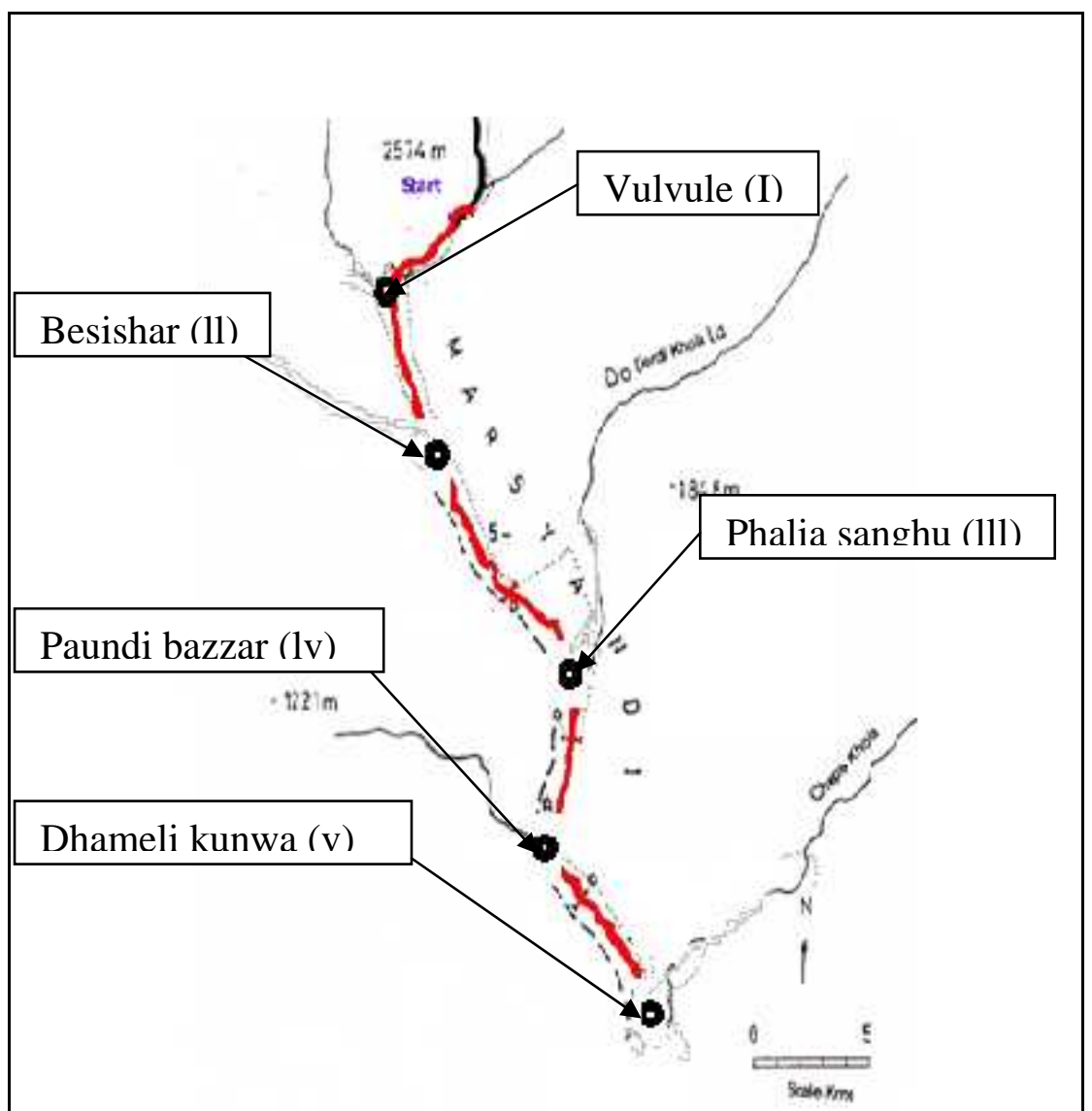

Figure 1. Map of the Marshyangdi river system of Lamjung. $\mathbf{0}$ (Black dot) $=$ Fish sampling points.

\section{Results}

A total of 26 species of fishes belonging to 5 orders, 6 families and 18 genera were recorded from the different localities of Marshyangdi river system in Lamjung district. Cyprinidae were most dominant group among the families represented the highest number of species (53.8\%) followed by Cobitidae (23.0\%), Sisoridae (7.7\%) and Channidae $(7.7 \%)$ while Anguillidae and Synbranchidae accounted each by $3.9 \%$ (Fig. 2). Systematic position of the fishes, 
local names and occurrence, status and abundance are listed in the table 1. Large numbers of fishes were recorded in locality $4^{\text {th }}$ and $5^{\text {th }}(58 \%$ to $50 \%)$ of the Marshyandi River (Tab. 1, Fig. 3) than dam-affected area of section $1^{\text {st }}, 2^{\text {nd }}$ and $3^{\text {rd }}(15 \%, 23 \%$ and $42 \%)$. Laboratory studies of gastrointestinal contents of phytoplankton and zooplankton and feeding behavior and spawning periodicity of fishes are listed in table 2. Migratory fishes like Anguilla bengalensis and short migratory fishes like Cprinion semiplotus and Mastacembelus armatus were rarely found in Marsyangdi River.

\section{Discussion}

In the assemblage structure cyprinids constituted the major group. Marked differences were evident between fish assemblages at the different sampling points during the study. Different water flows have direct influence on the population of Anguilla bengalensis, Tor putitora and Neolissochilus hexagonolepis in upper section of dam (locality I and II).

Dam significantly blocks nutrient flow (Welcomme, 1985) throughout the ecosystem affecting fisheries production in downstream owing reduction in water flow in winter season; hence fries, fingerlings and adult of migratory and residential fishes will be affected. Aquatic ecology and river biology from both upstream and downstream has been affected by damming as well as water quality, quantity and breeding grounds (Helland-Hansen et al., 1995). Hydropower generation enhances the development of the nation, but the river ecosystems are adversely affected especially to the fish species by damming which changes water quality (Shrestha, 2008). Mahaseer or Sahar (Tor tor and Tor putitora), Rajbam (Anguilla bengalensis ) are long range migratory fishes that cannot move up and down the closure of dam. Overexploitations, water pollution, destruction of habitat, low water level and flow modification have been categorized as the ultimate forcing factors that threaten global freshwater biodiversity (Naiman et al., 1995; Jackson et al., 2001; Malmqvist and Rundle, 2002; Rahel, 2002; Dudgeon et al., 2006).

\section{Impact of dam on fish species}

The Middle Marshyandi hydro dam extends near about more than $10 \mathrm{~km}$ and is situated by the side of Dumre-Besisahar road at about $33 \mathrm{~km}$ north-east from Dumre Bazar. Dam situated at Phalia Sangu in Lamjung District is a $55 \mathrm{~m}$ high of concrete dam constructed across the Marshyangdi River.Water represents one of the main resource opportunities for developing electric power generation for Nepal's future economic development (Jha and Chaudhary, 2003). The dam in Marshyangdi River has obstructed the seasonal migratory fishes from the Terai as well as local migratory fishes from the lower parts of Hilly region. According to the local people and fishermen, before the establishment of dam in the river, shoals of Gounch (Bagarius bagarius) and Thedi (Labeo angra) used to visit the areas above dam, and now they are completely disappeared. A continuous flow of water is regulated to the downstream from the dam. Many current loving species of fishes cannot migrate upstream because of physical barrier of the dam. Generally, discharge of water altering water volume influence composition of fish species especially migratory fishes (Agostinho et $a l .$, 2008). Long distance migratory fishes like Tor putitora, Anguilla bengalensis, 


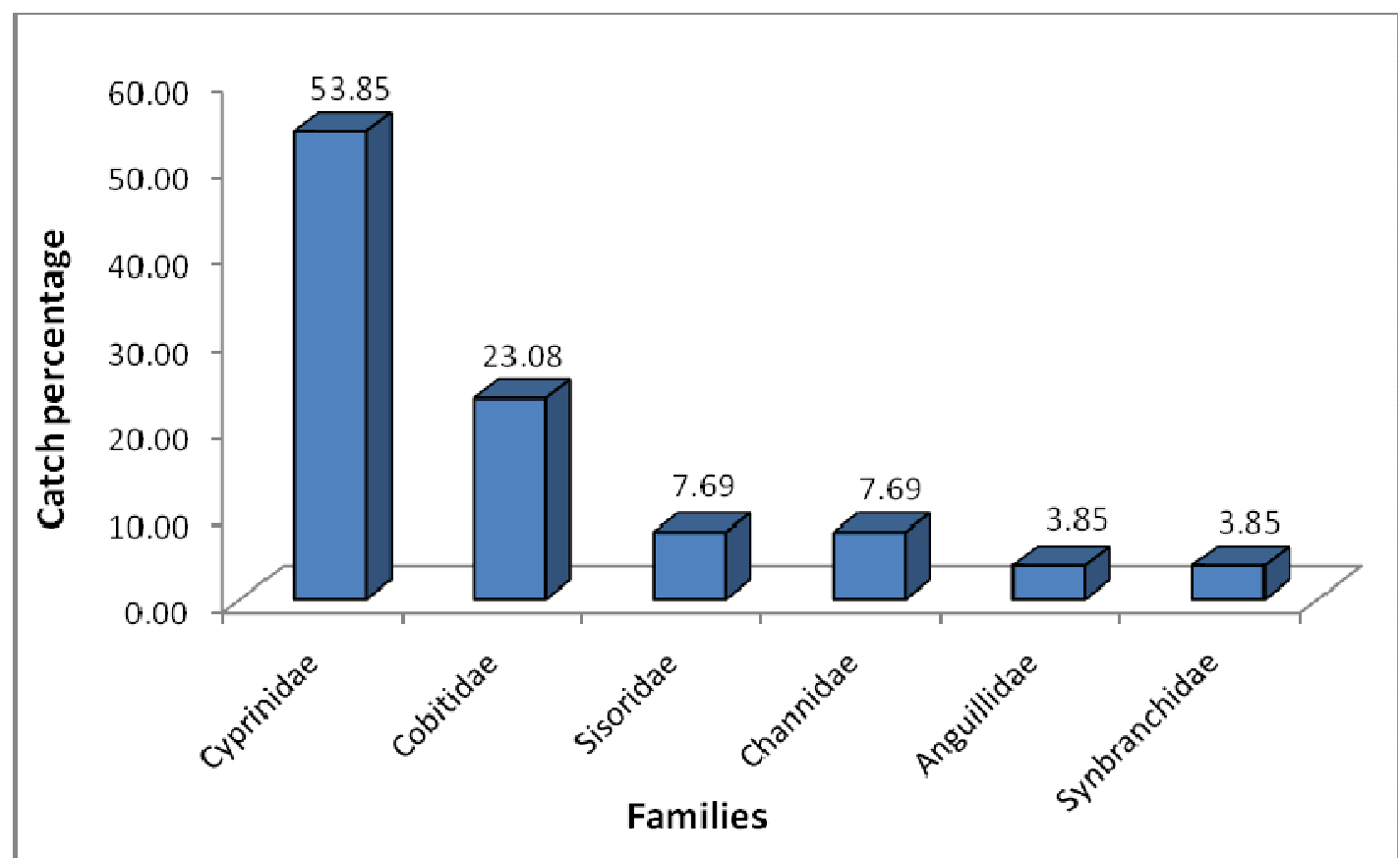

Figure 2. Catch percentage composition of different families.

Table 1. Systematic position, status and abundance of fishery resources in the different localities of Marshyangdi River.

\begin{tabular}{|c|c|c|c|}
\hline $\begin{array}{l}\text { Systematic position } \\
\text { A. Order: Cyriniformes } \\
\text { Division: Cyprini } \\
\text { Family: Cyprinidae } \\
\text { Sub family: Cyprinini }\end{array}$ & Local name & Status & Abundance \\
\hline $\begin{array}{l}\text { Genus:Neolissochilus } \text { Rainboth } \\
\text { 1. Neolissochilus hexagonolepis (McClelland) }\end{array}$ & Kate & Migratory & Common in IV, V. \\
\hline $\begin{array}{l}\text { Genus: Labeo Cuvier } \\
\text { 2. Labeo boga (Hamilton-Buchanan) } \\
\text { 3. Labeo dyocheilus (McClelland) } \\
\end{array}$ & $\begin{array}{l}\text { Thike } \\
\text { Gardi }\end{array}$ & $\begin{array}{l}\text { Short distance migratory } \\
\text { Short distance migratory }\end{array}$ & $\begin{array}{l}\text { Common in IV, V } \\
\text { Common in IV, V }\end{array}$ \\
\hline $\begin{array}{l}\text { Genus: Tor Grey } \\
\text { 4. Tor tor (Hamilton-Buchanan) } \\
\text { 5. Tor putitora (Hamilton-Buchanan) } \\
\end{array}$ & $\begin{array}{l}\text { Sahar } \\
\text { Sahar }\end{array}$ & $\begin{array}{l}\text { Migratory } \\
\text { Migratory }\end{array}$ & $\begin{array}{l}\text { Common in II to IV } \\
\text { Common in II to IV }\end{array}$ \\
\hline $\begin{array}{l}\text { Genus: Chagunius Smith } \\
\text { 6. Chagunius chagunio } \\
\text { (Hamilton-Buchanan) }\end{array}$ & Pathar chati & Short distance migratory & Common in IV,V \\
\hline $\begin{array}{l}\text { Genus: Cyprinion (Semiplotus) Bleeker } \\
\text { 7. Cyprinion semiplotus (McClelland) }\end{array}$ & Chepti & Short distance migratory & Rare in IV, V \\
\hline Sub family: Schizothoracinae & & & \\
\hline $\begin{array}{l}\text { Genus: Schizothorax Heckel } \\
\text { 8. Schizothorax molesworthi } \\
\text { (Chaudhari) }\end{array}$ & Chuche asla & Short distance migratory & Common in I to III \\
\hline
\end{tabular}


9. Schizothorax richardsonii (Grey) Genus: Schizothoraichthys McClelland

10. Schizothoraichthys progastus (McClelland) Buche asla Short dist. migratory Common in I to III Sub family: Danioninae (Rasborinae) Genus: Barilius Hamilton

Fageta

Chuche asla Short distance migratory Common in I to III

. Barilius bendelisis(Hamilton-Buchanan)

Fageta

Non migratory

Non migratory

Non migratory
Common in III to $\mathrm{V}$

Common in IV,V

Common in IV,V

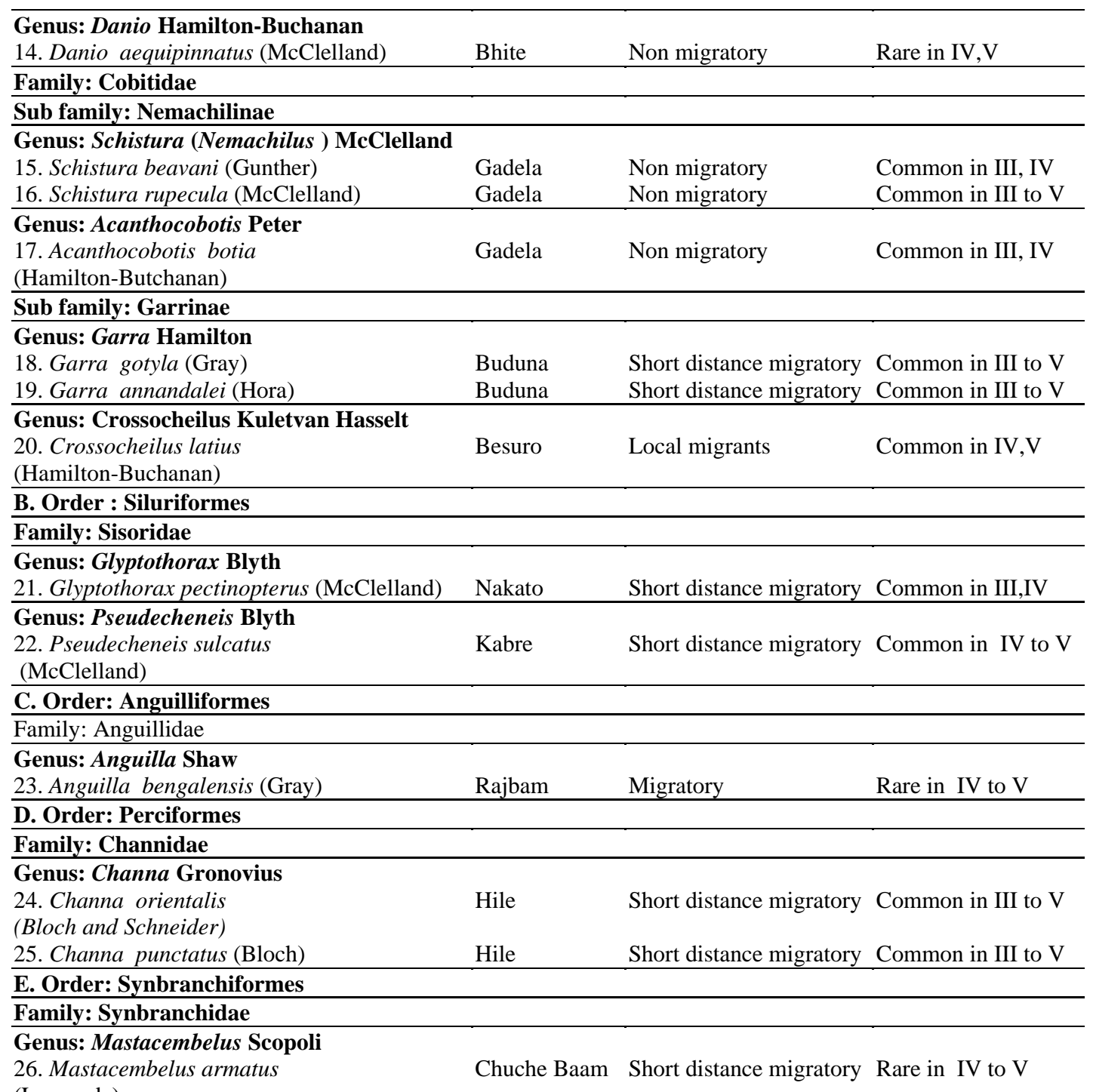

(Lacepede)

Locality I = Vulvule, locality II = Besishar, locality III = Phalia sanghu, locality IV = Paundi and locality, V = Dhamelikunwa 
Ram Bhajan Mandal and Dilip Kumar Jha / Our Nature (2013), 11(2): 168-176

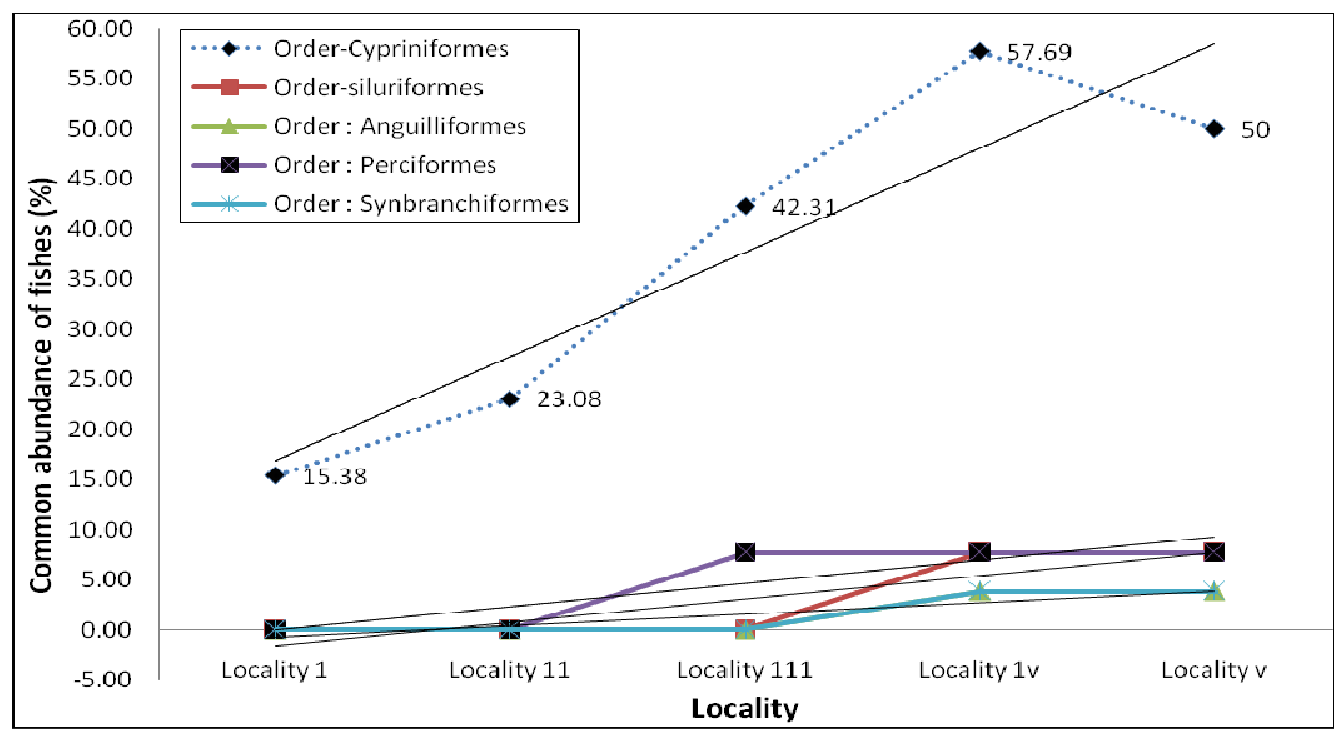

Figure 3. Abundance of fishes (\%) in different localities.

Table 2. Laboratory study of gastro-intestinal contents of fishes

\begin{tabular}{|c|c|c|}
\hline \multirow{2}{*}{ S.N. Name of species } & \multirow{2}{*}{\multicolumn{2}{|c|}{ 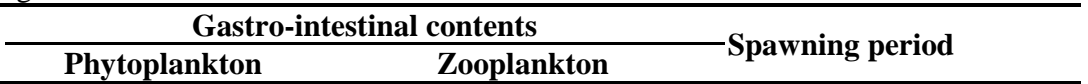 }} \\
\hline & & \\
\hline $\begin{array}{l}\text { Neolissochilus } \\
\text { hexagonolepis }\end{array}$ & $\begin{array}{l}\text { Spirogyra, Oscillatoria Branchionus, polyarthra, etc. } \\
\text { etc. }\end{array}$ & $\begin{array}{l}\text { Spawning period rages } \\
\text { from Sep. to Oct. }\end{array}$ \\
\hline Barilius barna & $\begin{array}{l}\text { Spirogyra, Chlorella, Diaptomus, Daphnia, Cyclop } \\
\text { Oscillatoria etc. } \\
\text { etc. }\end{array}$ & April. To Aug. \\
\hline Barilius bendelisis & $\begin{array}{lcc}\text { Spirogyra, } & \text { Chlorella, Ephimera, } & \text { Diaptomus } \\
\text { Oscillatoria etc. } & \text { Daphnia etc. } & \\
\end{array}$ & July to August. \\
\hline Barilius vagra & $\begin{array}{l}\begin{array}{l}\text { Spirogyra, Oscillatoria Diaptomus, Daphnia, Cyclop } \\
\text { etc. } \\
\text { larva etc. }\end{array} \\
\text { (a) }\end{array}$ & July to Sep. \\
\hline Chagunius chagunio & $\begin{array}{l}\text { Spirogyra, Oscillatoria Polyarthra, Filina species. } \\
\text { etc. }\end{array}$ & Aug. to Sep. \\
\hline Crossocheilus latius & $\begin{array}{l}\text { Spirogyra, Chlorella, } 0 \\
\text { Oscillatoria etc. }\end{array}$ & March To April. \\
\hline Danio aequipinnatus & $\begin{array}{l}\text { Spirogyra, Oscillatoria Diaptomus, Daphnia etc. } \\
\text { etc. }\end{array}$ & July to August. \\
\hline $8 \quad$ Garra annandalei & $\begin{array}{l}\text { Spirogyra, Oscillatoria, Polyarthra, Filina,Branchionu } \\
\text { Volvox etc. } \\
\text { species. }\end{array}$ & May To June. \\
\hline Garra gotyla & $\begin{array}{l}\text { Spirogyra, Oscillatoria, Polyarthra, Filina,Branchionu } \\
\text { Volvox etc. } \\
\text { species. }\end{array}$ & May To June. \\
\hline Labeo boga & $\begin{array}{l}\text { Spirogyra, Oscillatoria, } 0 \\
\text { etc. }\end{array}$ & June to August. \\
\hline Labeo dyocheilus & $\begin{array}{l}\text { Spirogyra, Oscillatoria, } 0 \\
\text { etc. }\end{array}$ & June to August. \\
\hline Cyprinion semiplotus & $\begin{array}{l}\text { Oscillatoria, } \\
\text { Vallisnaria } \text { etc. }\end{array}$ & June To July. \\
\hline Tor putitora & 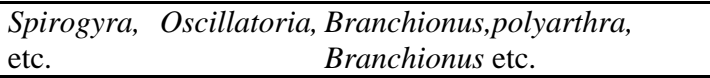 & Sep. to Oc. \\
\hline
\end{tabular}


Ram Bhajan Mandal and Dilip Kumar Jha / Our Nature (2013), 11(2): 168-176

\begin{tabular}{|c|c|c|}
\hline 14 & Tor tor & $\begin{array}{l}\begin{array}{l}\text { Spirogyra, Oscillatoria, Branchionus, polyarthra, Small Sep. to Oc. } \\
\text { etc. } \\
\text { fishes. }\end{array}\end{array}$ \\
\hline 15 & $\begin{array}{l}\text { Schizothorax } \\
\text { molesworthi }\end{array}$ & $\begin{array}{ll}\begin{array}{l}\text { Spirogyra, Chlorella, } 0 \\
\text { Oscillatoria etc. }\end{array} & \text { Breeds twice a year, Oct. } \\
\text { to Dec. and June. to March. }\end{array}$ \\
\hline 16 & $\begin{array}{l}\text { Schizothoraichthys } \\
\text { progastus }\end{array}$ & $\begin{array}{l}\text { Breeds twice a year, Oct. } \\
\text { to Dec. and June. to March. }\end{array}$ \\
\hline 17 & $\begin{array}{l}\text { Schizothorax } \\
\text { richardsonii }\end{array}$ & $\begin{array}{l}\text { Spirogyra, } \quad \text { Chlorella, } 0 \\
\text { Oscillatoria etc. }\end{array}$ \\
\hline 18 & Schistura. beavani & $\begin{array}{l}\text { Spirogyra, Chlorella Cyclops, Anax, Hemiptera etc April to May. } \\
\text { etc. }\end{array}$ \\
\hline 19 & Schistura rupecula & $\begin{array}{l}\begin{array}{l}\text { Spirogyra, Oscillatoria Pheritima, Hamiptera, Anax July to August. } \\
\text { etc. } \\
\text { etc. }\end{array} \\
\end{array}$ \\
\hline 20 & Acanthocobotis botia & $\begin{array}{l}\text { Spirogyra, Oscillatoria Pheritima, Hamiptera, Anax May to June. } \\
\text { etc. } \\
\text { etc. }\end{array}$ \\
\hline 21 & $\begin{array}{l}\text { Glaptothorax } \\
\text { pectinopterus }\end{array}$ & $\begin{array}{l}\text { Diaptomus, Daphnia, Cyclops March to July. } \\
\text { etc. }\end{array}$ \\
\hline 22 & $\begin{array}{l}\text { Pseudecheneis } \\
\text { sulcatus }\end{array}$ & Anax, Ranatra, Cyclops etc. $\quad$ May to June. \\
\hline 23 & Anguilla bengalensis & $\begin{array}{l}\text { Oscillatoria, decaying Crustaceans and small fishes. July to August. } \\
\text { matter. }\end{array}$ \\
\hline 24 & Channa orientalis & $\begin{array}{l}\text { Ephimera, Penaeus, small June to August. } \\
\text { fishes etc. }\end{array}$ \\
\hline 25 & Channa punctatus & $\begin{array}{l}\text { Ephimera, Penaeus, small June to August. } \\
\text { fishes etc. }\end{array}$ \\
\hline 26 & $\begin{array}{l}\text { Mastacembelus } \\
\text { armatus }\end{array}$ & decaying Crustaceans and small fishes. It breeds July to August. \\
\hline
\end{tabular}

Mastacembalus armatus are rarely found in Marshyangdi River. Localities I, II, III, IV and $\mathrm{V}$ constituted $15 \%, 23 \%, 42 \%, 58 \%$ and $50 \%$ fishes respectively which indicated that less number of fishes occurred due to damming effect in upper sections of the river (Fig. 3).

\section{Socioeconomic impact on local fishermen community}

Several ethnic groups like Kami, Damai, Sarki, Kumal, Majhi, Gayane etc. residing at the river bank adopt fishing as their traditional profession. These fishing communities are very poor, uneducated and highly vulnerable; so their livelihood is highly affected by heavy decline of fish catch after the hydropower projects.

\section{Recommendations}

Following recommendations are suggested:

- Development of fish ladder especially for the population of cold water fishes like Schizothorax spp, Tor spp, Neolissochilus hexagonolepis and other migratory fishes (Anguilla bengalensis) are affected by the dam.

- Maintenance of fish population by constructing spawning channel or stocking with hatchery-produced fish seeds.

- Establishment of international coldwater center in Nepal to carry out programs of research, conservation and development of coldwater fishery of the Himalayan region.

\section{Acknowledgements}

The authors thank Directorate of Research, Institute of Agriculture and Animal Science, 175 
Rampur for financial support. We thank Mr. Rambhai Kumal, local fisherman for his help in fish sampling at different sections. Thank is also due to Ram Nath Dhakal, senior lab boy, Lamjung campus, for his help in laboratory works.

\section{References}

Agostinho, A.A., F.M. Pelicice and L.C. Gomes 2008. Dams and the fish fauna of the Neotropical region: impacts and management related to diversity and fisheries. Braz. J. Biol. 68(4): 1119-1132.

APHA 2005. Standard methods for the examination of water and waste water $\left(21^{\text {th }}\right.$ ed). American Public Health Association, American Water Works Association 1015, Fifteenth street NW, Washington D.C. 1268 p.

Burton, P.J., A.E. Balisky, L.P. Coward, S.G. Cumming and D.D. Kneshwaw 1992. The value of managing biodiversity. The Forestry Chronicle 68(2): 225-237.

Dudgeon, D., A.H. Arthington, M.O. Gessner, Z. Kawabata, D. Knowler, C. Le've^que, R.J. Naiman, A.H. Prieur-Richard, D. Soto and M.L.J. Stiassny 2006. Freshwater biodiversity: Importance, threats, status, and conservation challenges. Biological Reviews 81: 163-182.

Goswami, S.C. 2004. Zooplankton methodology, collection and identification. A field manual, National Institute of Ocenography, Dona population, Goa 403004.

Gubhaju, S.R. 2012. Impact of damming on the environment of flow and persistence of native fishes. In Proceedings of the consultative workshop on fish conservation in Nepal (Eds. S.K. Wagle and N. Pradhan). pp. 79-93.

Gurung, T.B. 2012. Native fish conservation in Nepal: Challenges and opportunities. Nepalese Journal of Biosciences 2: 71-79.

Helland-Hansen, E., T. Holtedahl and K.A. Liye 1995. Enviromental Effects, Vol. 3. Hydropower Development, Norwegian Institute of Technology.

HMGN/MFSC 2002. Nepal Biodiversity Strategy. Ministry of Forests and Soil Conservation. HMG, Nepal. 132p.

IOC 2010. Microscopic and molecular methods for quantitative phytoplankton analysis. Intergovernmental Ocenographic Commision
(IOC) manuals guides no. 55, Paris UNESCO.

Jackson, R.B., S.R. Carpenter, C.N. Dahm, D.M. McKnight, R.J. Naiman, S.L. Postel, S.W. Running 2001. Water in a changing world. Ecological Applications 11: 1027-1045.

Jha, B.R., H. Waidbacher, S. Sharma and M. Straif 2007. Study of the dams in different rivers of Nepal showed more severe impact in upstream compared to downstream. In International Conference on Small Hydropower - Hydro Sri Lanka, 22-24 October, 2007. pp. 1-9.

Jha, J. and R. Chaudhary 2003. Hydropower development and fish diversity. A paper presented at the Workshop on Hydropower Dams: Impact on Fish Biodiversity and Mitigation Approaches, Kathmandu.

Malmqvist, B. and S. Rundle 2002. Threats to the running water ecosystems of the world. Environmental Conservation 29(2): 134-153.

Naiman, R.J., J.J. Magnuson, D.M. McKnight, J.A. Stanford and J.R. Kar 1995. Freshwater ecosystems and their management: A national initiative. Science 270: 584-585.

Rahel, F.J. 2002. Homogenization of freshwater faunas. Annual Review of Ecology and Systematic 33: 291-315.

Rai, A.K.2008. Environmental impact from river damming for hydroelectric power generation and means of mitigation, Hydro Nepal. Journal of Water, Energy and Environment 1(2): 22-25.

Sarkar, U.K., A.K. Pathak, A.K. Pandian, A. Pandey, V.K. Dubey and W.S. Lakra 2012. Freshwater fish biodiversity in the River Ganga, India: Changing pattern, threats and conservation perspectives. Riviews in Fish Biology and Fisheries 22(1): 251-272.

Shrestha, J. 1999. Cold water fish and fisheries in Nepal. In Fish and Fisheries at high altitudes, Asia, FAO, (Ed. Petr). Fisheries technical paper 385: 13-40.

Shrestha, T.K. 2008. Ichthyology of Nepal. A study of fishes of the Himalayan water. Himalayan Ecosphere, Kathmandu, Nepal. 388p.

Welcomme, R.L. 1985. River fisheries. Rome. FAO Fisheries Technical paper 262: 330.

Xie, P. 1999. Gut contents of silver carp Hypophthalmichthys molitrix, and the disruption of a centric diatom Cyclotella on passage through the esophagus and intestine. Aquaculture 180: 295-305. 